\title{
Functional and non-functional types of adrenal tumors: a case
}

\section{series [version 1; peer review: 1 not approved]}

\section{Dwiki Haryo Indrawan1, Fauriski Febrian Prapiska (iD), Syah Mirsya Warli (iD)3, Bungaran Sihombing², Ginanda Putra Siregar²}

\footnotetext{
${ }^{1}$ Urology, Faculty of Medicine Universitas Indonesia- Cipto Mangunkusumo National Hospital, Jakarta, DKI Jakarta, Indonesia 2Urology Division Of Surgery Department, Faculty of Medicine Universitas Sumatera Utara - H. Adam Malik General Hospital, Medan, Sumatera Utara, 20136, Indonesia

3Urology, Faculty of Medicine - Universitas Sumatera Utara General Hospital, Medan, Sumatera Utara, Indonesia
}

V1 First published: 28 Jul 2021, 10:675

https://doi.org/10.12688/f1000research.51593.1

Latest published: $28 \mathrm{Jul} 2021, \mathbf{1 0 : 6 7 5}$

https://doi.org/10.12688/f1000research.51593.1

\section{Abstract}

Adrenal gland masses could be classified into functional, malignant, or benign. An adrenal cortical adenoma is one of the most common incidentalomas found with either functional or non-functional type. Pheochromocytoma is a neural crest cell origin tumor associated with catecholamine production. A classic triad of headache, sudden episodic perspiration, and tachycardia marked a pheochromocytoma. We report three patients with adrenal tumors. First, a 52-year-old woman with complaints of pain in the left flank suggests a left kidney tumor. The patient has an increased blood pressure intraoperatively. Adrenal cortical adenoma was found postoperatively. The second case is an Indonesian male 27-year-old with pain in the upper right abdomen. Intraoperative, the patient also has an escalation in blood pressure. Antihypertensive drugs are also used in this patient. Postoperatively, a pathology result of pheochromocytoma was revealed from this patient. The third case, adrenal myelolipoma, was suspected in a 48-year-old male and underwent surgery because of tumor growth. Later, a histopathological examination revealed myelolipoma of the adrenal. Management of adrenal tumor should be done individually based on each patient. In the first and second cases, blood pressure was unstable intraoperatively and was managed using several drugs, and was stable at follow-up. In the third case was no hemodynamic problem. In the case of an adrenal tumor, management tailoring should be based on the individual patient.

Keywords

Adrenal cortical adenoma, adrenal tumor, pheochromocytoma, adrenal myelolipoma

\section{Open Peer Review \\ Approval Status \\ 1 \\ version 1 \\ 28 Jul 2021 \\ view \\ 1. Christina Pamporaki (D), University Hospital \\ Carl Gustav Carus at the TU Dresden, \\ Dresden, Germany \\ MKIII, Universitätsklinikum Carl Gustav \\ Carus, Dresden, Germany}

Any reports and responses or comments on the article can be found at the end of the article. 
Corresponding author: Fauriski Febrian Prapiska (fauriski.febrian@usu.ac.id)

Author roles: Indrawan DH: Conceptualization, Data Curation, Formal Analysis, Methodology, Project Administration, Writing - Original Draft Preparation; Prapiska FF: Conceptualization, Data Curation, Formal Analysis, Methodology, Project Administration, Resources, Supervision, Writing - Review \& Editing; Warli SM: Supervision, Validation, Visualization; Sihombing B: Supervision, Validation, Visualization; Siregar GP: Supervision, Validation, Visualization

Competing interests: No competing interests were disclosed.

Grant information: The author(s) declared that no grants were involved in supporting this work.

Copyright: (c) 2021 Indrawan DH et al. This is an open access article distributed under the terms of the Creative Commons Attribution License, which permits unrestricted use, distribution, and reproduction in any medium, provided the original work is properly cited.

How to cite this article: Indrawan DH, Prapiska FF, Warli SM et al. Functional and non-functional types of adrenal tumors: a case series [version 1; peer review: 1 not approved] F1000Research 2021, 10:675 https://doi.org/10.12688/f1000research.51593.1

First published: 28 Jul 2021, 10:675 https://doi.org/10.12688/f1000research.51593.1 


\section{Introductions}

The adrenal gland is a unique retroperitoneal endocrine organ that is different if compared with other retroperitoneal structures in embryological, anatomical, and their role in homeostasis. Tumors of the adrenal gland can be classified as functional or non-functional. The tumors may arise from the adrenal gland or could be secondary lesions. They may be benign or malignant. ${ }^{1,2}$ Tumors of the adrenal gland are relatively common. The prevalence of adrenal gland tumors is three to ten percent of the human population. ${ }^{3}$ Adrenal tumor sometimes found as an incidentaloma, which means the tumor more than $1 \mathrm{~cm}$ in size was found during an imaging study with indications other than the adrenal condition, but this excludes the patients who were done an imaging study during cancer work-up. Adrenal tumors are known to be one of the most commonly found incidentaloma. ${ }^{4-8}$

Adrenal masses could be classified into functional, malignant, or benign masses. In functional terms, adenoma causing Conn's of Cushing's syndrome, pheochromocytoma, aldosteronoma, and adrenal carcinoma were included. While malignant were comes from metastases, carcinoma, lymphoma, or neuroblastoma. Last but not least, benign masses consisted of nonfunctioning adenoma, angiomyolipoma, cysts, and hemorrhage. ${ }^{9}$ Pheochromocytomas are neural crest cell tumors and linked with catecholamine production. ${ }^{10}$ The initial examination, usually using ultrasound as the diagnostic modality, could be detected in $90 \%$ of cases as an enlargement of the adrenal gland. ${ }^{11}$ The founding could be variable from solid to mixed cystic and solid to cystic. ${ }^{12}$ Pheochromocytomas patients often present with hypertension, tachycardia, headaches, palpitations, diaphoresis, chest pain, anxiety, and even weight loss. Around $10 \%$ of the patients do not have hypertension as their primary symptom. ${ }^{13}$

An adrenal cortical adenoma is one of the most common incidentalomas found. ${ }^{13}$ An adenoma mass should be grouped into functioning and non-functioning adrenal adenomas. It should be noted that functioning and non-functioning adenomas could not be classified using imaging techniques. ${ }^{14}$ Adenomas show a uniform hypoechoic mass relative to the fat. Adenomas are relatively small mass made them be difficult to be found during an ultrasound examination. ${ }^{9}$

The treatment for adrenal tumor requiring surgery usually because of the treatment failure in functional adrenal masses or a malignant tumor for either primary adrenal cortical carcinoma or solitary metastasis from nonadrenal sources, such as lungs, breasts, kidneys, and melanomas. ${ }^{15}$ Today, laparoscopic adrenalectomy is the first choice for adrenal disorder surgical procedures. But, there are some conditions that are requiring open adrenalectomies, such as patients with adrenal carcinoma, large pheochromocytoma with blood pressure that may be hard to control, and patients that are requiring a simultaneous abdominal procedure. ${ }^{16}$ But the absolute contraindications for adrenalectomy are extensive metastatic disease, uncorrected coagulopathy, and severe cardiopulmonary disease that precludes anesthesia. ${ }^{14}$ The authors report two cases of adrenal glands tumors requiring open adrenalectomy. This study was conducted with surgical CARE checklist guideline as a guidance. ${ }^{15}$

\section{Case 1}

A 52-year-old Indonesian female presented with pain on the left flank. Pain has been felt for six months. Hematuria was found. History of diabetes was found with the highest fasting glucose reported was $159 \mathrm{mg} / \mathrm{dL}$, hypertension was found with a regular blood pressure of about $170 / 100 \mathrm{mmHg}$ - patient with a history of percutaneous cardiac intervention four months ago. The patient was referred to our Regional Referral Hospital with a left adrenal tumor. The patient also has depression diagnosed by a psychiatrist having 23-score in Beck Depression Inventory-II (BDI II) questionnaire. It has been experienced by the patient two years ago, initiated by the death of her husband. The patient also felt a problem in her marriage, as she never felt intimate with her husband from the first day of their marriage. The patient was diagnosed with an adrenal tumor for the last five years, and since then, she has felt useless in her life. From the radiologic examination, we found a mass from the suprarenal organ, suggestive of an adrenal tumor as a conclusion (Figure 1). Thus, we used the left adrenal tumor as a working diagnosis.

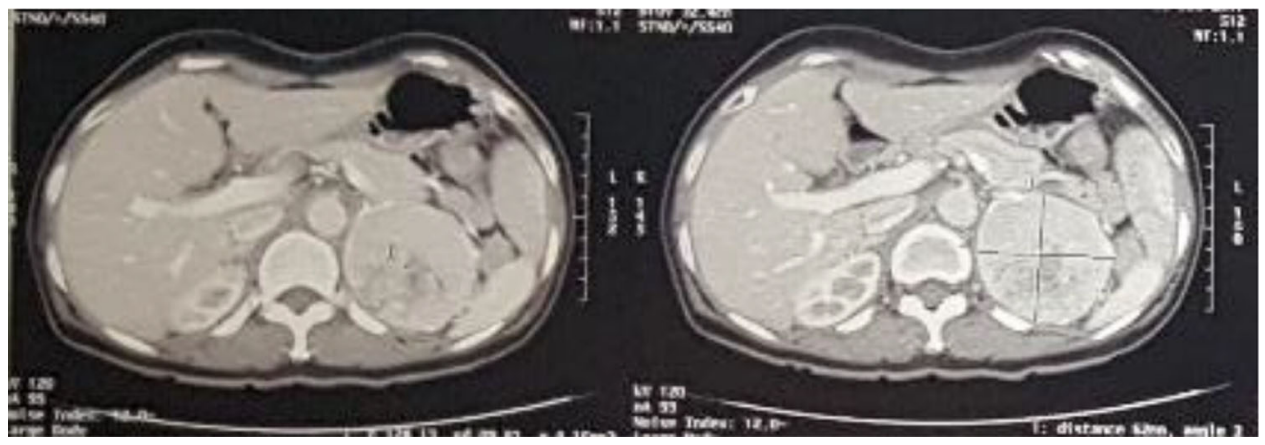

Figure 1. CT Scan showed a left mass suggestive adrenal tumor. 

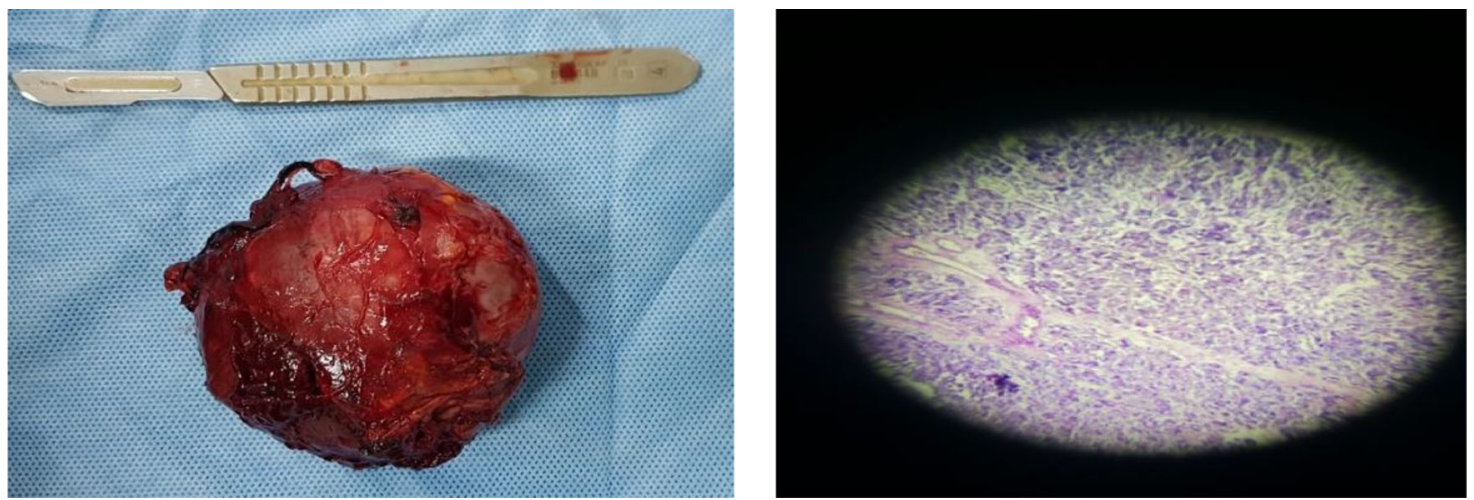

Figure 2. Macroscopic and microscopic tumor.

Adrenalectomy was performed for the left adrenal tumor. During the operation, unstable blood pressure was noted and could increase over $200 \mathrm{mmHg}$. Then the anesthesiologist used several medications to lower the blood pressure immediately. The problems with her blood pressure did not persist after the surgery. The highest blood pressure after adrenalectomy was $130 / 80 \mathrm{mmHg}$. Post adrenalectomy mass was sent to the pathology department in order to perform a pathology examination (Figure 2). The result came within one week after the procedures and revealed a picture of tumor cells forming nests is largely separated by fibrous fibers by an invasion of blood vessels. Tumor cells with rounded and oval nuclei are enlarged, rough chromatin, protruding nuclei, cytoplasm partly eosinophilic, partly clear, and bubbly. Abnormal mitosis is easy to find. The stroma consists of infiltrated fibrous connective tissue, with a conclusion of adrenal cortical adenoma.

During the follow-up, the patient shows a normal condition, with normal blood pressure (maximum $125 / 80 \mathrm{mmHg}$ ) but the fasting glucose still not yet within the normal value.

\section{Case 2}

We were reporting an Indonesian male 27-year-old with pain in the upper right abdomen. The pain has been experienced by the patient since one month ago and aggravating within this week. A mass was felt by the patient on the upper right abdomen. No hematuria was reported, no passing stone, no history of hypertension and diabetes. From physical diagnosis, we found a positive ballottement test on the right flank. Other physical examinations were within normal limits.

During the preoperative preparation, blood pressure was within the normal limit. An initial complete blood test showed normal hemoglobin $(12.3 \mathrm{~g} / \mathrm{dL})$, white blood cells $(9,800 / \mu \mathrm{L})$, and thrombocyte $(319,000 / \mu \mathrm{L})$. Normal glucose analysis was found, different from our first case.

The radiological examination found an adrenal tumor (Figure 3). Based on the radiological examination, the right adrenal tumor was suspected as our diagnosis.

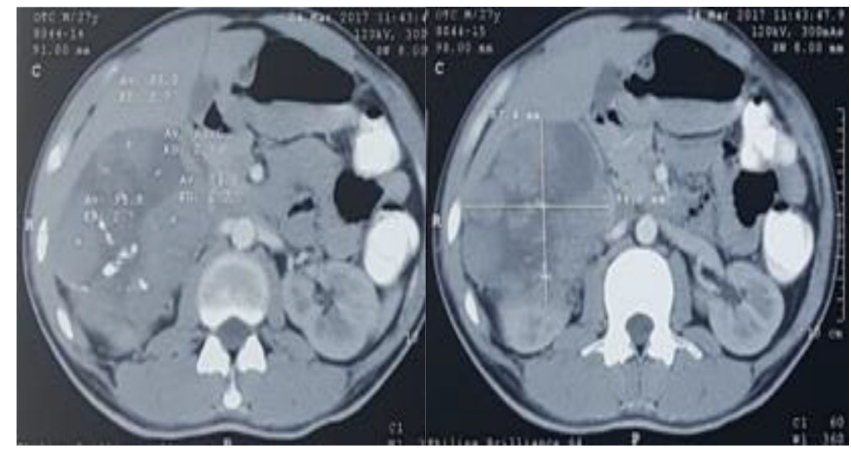

Figure 3. CT Scan showed a left mass suggestive adrenal tumor. 

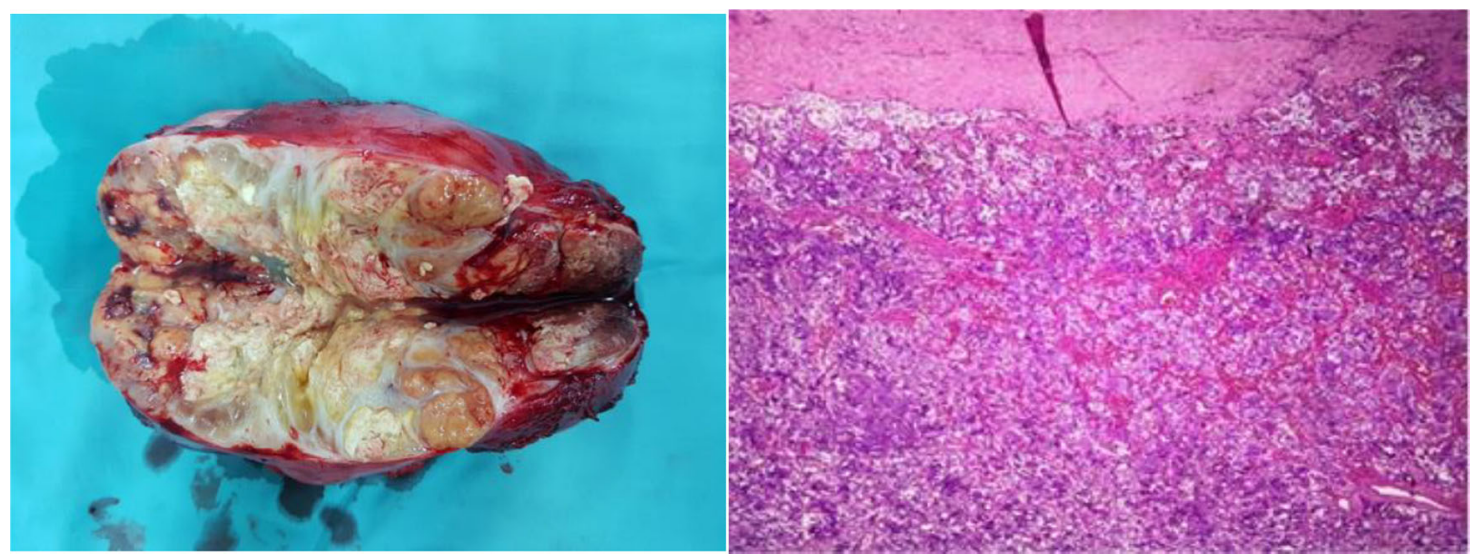

Figure 4. Macroscopic and microscopic tumor (HE).

Right adrenalectomy was performed on December, $7^{\text {th }}$ 2017. We found a bulging mass from the posterior. Then we opened the white line of Toldt. The next step was releasing the mass from lateral, superior, inferior, and the last, media. Anterior pedicels and branches from the vena cava and aorta towards the right adrenal were then ligated and cut. Intraoperatively, several antihypertensive drugs were used by the anesthesiologist to maintain the blood pressure at a lower level. Normal blood pressure was preserved after removal of the adrenal gland.

The mass on the right upper abdomen was inspected by the pathology department on December, $8^{\text {th }} 2017$, and after the next five days, a result was reported, which was a pheochromocytoma (Figure 4). The follow-up was done, and the patient did not show any problem with the blood pressure, blood glucose, and the complete blood count was normal.

\section{Case 3}

We were reporting a 48-year-old male who came to urology clonic referred from digestive surgery consultant with an intraabdominal tumor suspected with adrenal myelolipoma. The mass was felt to increase in size for the last one month. No pain on palpation, no history of hematuria, cloudy urine, or passing stone. The patient also complained of fatigue and shortness of breath. On examination, hemodynamic was within normal limits. On urological examination, ballotement was found on the right flank without any tenderness. From computed tomography scan, an upper right abdomen mass was found, pushing liver to the superior and kidney to the inferior (Figure 5). The mass sized $12.8 \times 10 \times 10 \mathrm{~cm}$, suspected of adrenal myelolipoma.

We performed a tumor removal for this patient (Figure 6). Intraoperatively, the hemodynamic remained stable. Based on this finding, we could rule out pheochromocytoma. Later, a histopathological examination revealed adrenal preparations appear to be the proliferation of mature fat cells with a round, oval, eccentric, smooth chromatin nucleus, numerous cytoplasm and clear, between groups of fat cells appear to group hematopoietic cells, at certain focus looks interstitial bleeding (Figure 7). No signs of malignancy were found in this preparation, the impression of Myelolipoma of Adrenal.
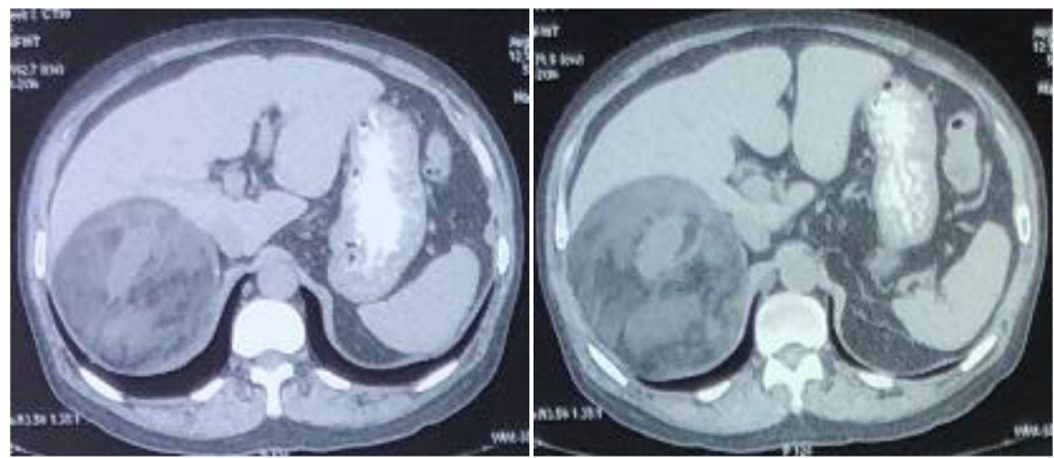

Figure 5. CT Scan examinaton showed an upper right abdomen mass. 

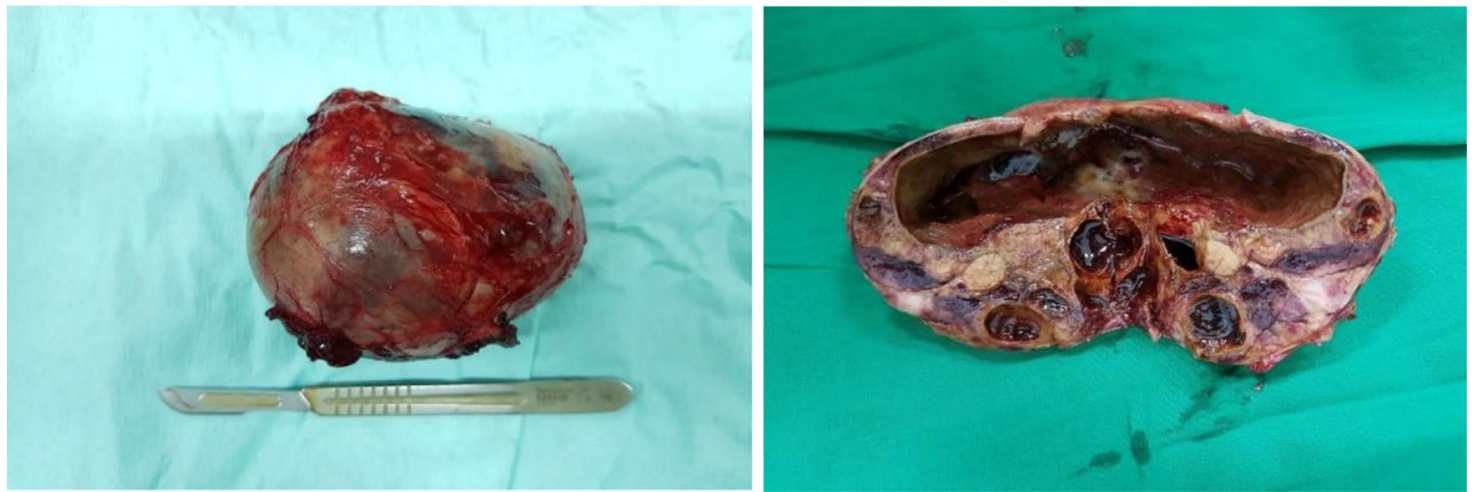

Figure 6. Macroscopic tumor after adrenelectomy.
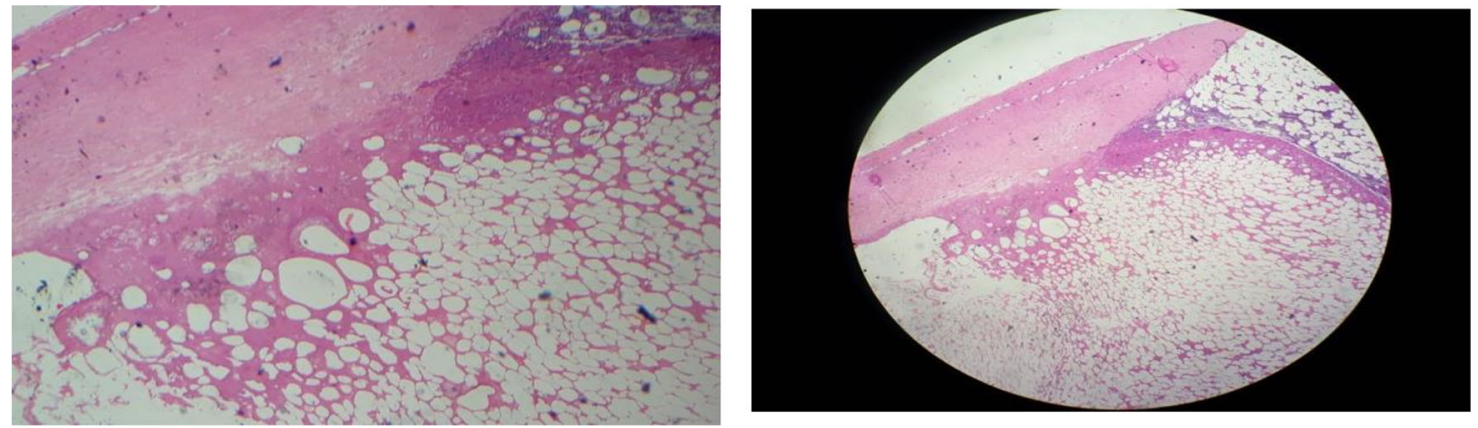

Figure 7. Microscopic of tumor.

\section{Discussion}

From this case series, we reported two cases of adrenal tumors, with one case of adrenal cortical adenoma and one case of pheochromocytoma. Adenomas are the most common benign tumors from the adrenal gland. From our first case, an adrenal cortical adenoma was found associated with diabetes, hypertension, and depression. This case is suggestive of a functional adrenal cortical adenoma. The glucocorticoids' production from the adenoma could increase hypercortisolism, or known as Cushing syndrome. ${ }^{17}$

Cortisol production from benign adenomas often results from a unilateral hyperplastic mass, although a bilateral one might also happen. Systemic manifestations from hypercortisolism are central obesity, dyslipidemia, or hypertension. ${ }^{17}$ In our patient, we found hypertension without dyslipidemia or central obesity. On the other hand, one patient may come to clinical practice with a high blood glucose level, and when screened for hypercortisolism, he/she may have a subclinical Cushing syndrome. ${ }^{18}$ In our patient, we have a high blood glucose level, which becomes normal after adrenalectomy. Similar results were stated by Midorikawa and Mitchel. They found that an adrenalectomy procedure may improve glucose control together with hypertension. ${ }^{19,20}$ Cushing syndrome may also be related to depression. Labeur et al. also stated this manifestation in their study. ${ }^{21}$

Pheochromocytoma is a tumor of the catecholamine-producing cells of the adrenal medulla. The classic presenting sign of pheochromocytoma patients is paroxysmal hypertension, while the other could demonstrate persistent high blood pressure and normotensive. ${ }^{17}$ There is a classic hallmark triad of pheochromocytoma, headache, sudden episodic perspiration, and tachycardia. ${ }^{22}$ In our case, we failed to find any clinical manifestation, which has been stated earlier. Our patient has normal blood pressure without headache, perspiration, or even tachycardia. This might be similar to a study from Adler et al. They said as many as $20 \%$ of pheochromocytoma patients could present with no symptom at all. ${ }^{23}$

Intraoperatively, both of our cases showed similar symptoms with a spike in blood pressure. This manifestation has also been reported by Kakoki et al. ${ }^{24}$ However, after the adrenalectomy procedure, the patients did not sustain any elevated blood pressure. This also happened during the follow-up.

Adrenal myelolipoma is a rare, non-functional, and benign neoplasm of the adrenal gland. ${ }^{25}$ Because of the rarity, in the past adrenal myelolipomas, were found during the autopsy. Nowadays, because of radiological studies such as 
ultrasonography, computed tomography, and magnetic resonance imaging, incidentaloma has become more commonly found. ${ }^{26}$ The management of this tumor is usually conservative because most of them are asymptomatic. However, surgical intervention is suggested in a large tumor (larger than six cm). ${ }^{27}$ So, the management is based on the size and the symptoms of the tumor. ${ }^{28}$

\section{Conclusions}

We report a case series with three cases of adrenal tumor. The first case is an adrenal cortical adenoma suggestive a functional type. The second case is a pheochromocytoma without the classic hallmark. Both cases have unstable intraoperative blood pressure and have to be stabilized using several medications. During the follow-up, normotensive was achieved in both patients. The third cases have no hemodynamic disturbance in preoperative, intraoperative, and postoperative. In case of adrenal tumor, management tailoring should be based on individual patient.

\section{Acknowledgement}

The authors would like to thank everyone who supported this study. Special thanks are given to Adam Malik General Hospital and Universitas Indonesia which fully supported the authors during writing period.

\section{Consent}

Written informed consent for publication of their clinical details and/or clinical images was obtained from the patients.

\section{Data availability}

All data underlying the results are available as part of the article and no additional source data are required.

1. Munver R, YatesJK, Degen MC: Surgical Anatomy of the Adrenals. In: Campbell-Walsh Urology. 11th Ed. Philadelphia: Elsevier; 2016; 1519-1527.

2. Palter $\mathrm{V}$, Devon $\mathrm{K}$, Hallet J, et al.: Tumours of Adrenal Glands. In: Wright F, Escallon J, Cukier M, et al. (eds). Surgical Oncology Manual. Cham: Springer; 2016

3. Else T, Kim AC, Sabolch A, et al.: Adrenocortical Carcinoma. Endocr Rev. 2014; 35(2): 282-326.

PubMed Abstract | Publisher Full Text | Free Full Text

4. Adrenal UR: Surgery, Basic Science and Clinical Evidence. In: Norton JA, Bollinger RR (eds). Springer; 2001.

5. Linos DA: Adrenal incidentaloma (adrenaloma). Hormones (Athens). 2003; 2: 12-21.

PubMed Abstract | Publisher Full Text

6. Bulow $B$, Jansson $S$, Juhlin $C$, et al.: Adrenal incidentaloma - followup results from a Swedish prospective study. Eur J Endocrinol. 2006; 154: 419-423.

PubMed Abstract | Publisher Full Text

7. Anagnostis $P$, Karagiannis A, Tziomalos $K$, et al.: Adrenal incidentaloma: a diagnostic challenge. Hormones (Athens). 2009; 8: $163-184$.

PubMed Abstract | Publisher Full Text

8. Kanagarajah P, Ayyathurai R, Manoharan M, et al.: Current concepts in the management of adrenal incidentalomas. Urol Ann. 2012; 4: 137-144.

PubMed Abstract | Publisher Full Text | Free Full Text

9. Conder G, Rendle J, Kidd S, et al.: A-Z of Abdominal Radiology. Cambridge, UK: Cambridge University Press; 2009. Reference Source

10. Mittendorf EA, Evans DB, Lee JE, et al.: Pheochromocytoma: advances in genetics, diagnosis, localization, and treatment. Hematol/Oncol Clin North Am. 2007; 21: 509-525. PubMed Abstract | Publisher Full Text

11. Kidneys HM, Glands A: Ultrasound Teaching Manual Hofer Matthias, Th ieme. 1999; 37-50.

12. Bowerman RA, Silver TM, Jaffe MH, et al.: Sonography of adrenal pheochromocytomas. AJR Am J Roentgenol. 1981; 137: 1227-1231. PubMed Abstract | Publisher Full Text

13. Pinto A, Barletta JA: Adrenal tumors in adults. Surg Pathol Clin 2015; 8: 725-749. PubMed Abstract | Publisher Full Text

14. Farrugia FA, Martikos G, Surgeon C, et al.: Radiology of the adrenal incidentalomas: Review of the literature. Endocr Regul. 2017; 51:
35-51

PubMed Abstract | Publisher Full Text

15. Agha RA, Fowler AJ, Saeta A, et al.: The SCARE Statement: Consensus-based surgical case report guidelines. Int J Surg. 2016 Oct; 34: 180-186. PubMed Abstract | Publisher Full Text

16. Lim SK, Rha KH: Surgery of the adrenal glands. In: Wein AJ, Kavoussi LR, Partin AW, et al., editors. Campbell-Walsh urology. 11th ed. Philadelphia: Elsevier; 2015. p.1577.

17. Vaughan ED: Open Approaches to The Adrenal Gland In: Smith JA Howards SS, McGuire EJ, et al. (eds). Hinmans's Atlas of Urologic Surgery. 3rd ed. Philadelphia: Elsevier. 2010. p. 1103-1110.

18. Kutikov A, Crispen PL, Uzzo RG: Pathophysiology, evaluation, and medical management of adrenal disorders. In: Wein AJ, Kavoussi LR, Partin AW, et al., editors. Campbell-Walsh urology. 11th ed. Philadelphia: Elsevier; 2015. p.1535-1547.

19. Catargi B, Rigalleau V, Poussin A, et al.: Occult Cushing's syndrome in type-2 diabetes. / Clin Endocrinol Metab. 2003; 88(12): 5808-5813. PubMed Abstract| Publisher Full Text

20. Midorikawa $\mathrm{S}$, Sanada $\mathrm{H}$, Hashimoto $\mathrm{S}$, et al.: The improvement of insulin resistance in patients with adrenal incidentaloma by surgical resection. Clin Endocrinol (Oxf). 2001; 54(6): 797-804. PubMed Abstract | Publisher Full Text

21. Mitchell IC, Auchus RJ, Juneja K, et al.: "Subclinical Cushing's syndrome" is not subclinical: improvement after adrenalectomy in 9 patients. Surgery. 2007; 142(6): 900-905, discussion 905.e1. PubMed Abstract | Publisher Full Text

22. Labeur M, Arzt E, Stalla GK, et al.: New perspectives in the treatment of Cushing's syndrome. Curr Drug Targets Immune Endocr Metabol Disord. 2004 Dec; 4: 335-342. PubMed Abstract | Publisher Full Text

23. Bravo EL, Tagle R: Pheochromocytoma: state-of-the-art and future prospects. Endocr Rev. 2003; 24(4): 539-553. PubMed Abstract | Publisher Full Text

24. Adler JT, Meyer-Rochow GY, Chen H, et al.: Pheochromocytoma: current approaches and future directions. Oncologist. 2008; 13(7): 779-793.

PubMed Abstract | Publisher Full Text

25. Kakoki K, Miyata Y, Shida Y, et al.: Pheochromocytoma multisystem crisis treated with emergency surgery: A case report and literature review. BMC Res Notes. 2015 Dec 9; 8: 758. PubMed Abstract | Publisher Full Text | Free Full Text 
26. Feng $\mathrm{C}$, Jiang $\mathrm{H}$, Ding $\mathrm{Q}$, et al.: Adrenal myelolipoma: a mingle of progenitor cells? Med Hypotheses. 2013; 80 819-822.

PubMed Abstract | Publisher Full Text

27. Wani N, Kosar T, Rawa I, et al.: Giant adrenal myelolipoma: incidentaloma with a rare incidental association. Urol Ann. 2010; 2(3): 130

PubMed Abstract | Publisher Full Text | Free Full Text
28. Nabi J, Rafiq D, Authoy F, et al.: Incidental detection of adrenal myelolipoma: a case report and review of literature. Case Rep Urol. 2013; 2013: 1-3.

PubMed Abstract | Publisher Full Text | Free Full Text

29. Ramirez M, Misra S: Adrenal myelolipoma: To operate or not? A case report and review of the literature. Int J Surg Case Rep. 2014; 5(8): 494-496.

PubMed Abstract | Publisher Full Text | Free Full Text 


\section{Open Peer Review}

\section{Current Peer Review Status: $\mathrm{X}$}

\section{Version 1}

Reviewer Report 11 April 2022

https://doi.org/10.5256/f1000research.54779.r128202

(C) 2022 Pamporaki C. This is an open access peer review report distributed under the terms of the Creative Commons Attribution License, which permits unrestricted use, distribution, and reproduction in any medium, provided the original work is properly cited.

\section{Christina Pamporaki}

${ }^{1}$ Department of Medicine III, University Hospital Carl Gustav Carus at the TU Dresden, Dresden, Germany

2 MKIII, Universitätsklinikum Carl Gustav Carus, Dresden, Germany

In the article by Indrawan et al. the authors describe a case series of three patients with adrenal masses. In particular, they describe a case with adrenal cortical adenoma, a second case with pheochromocytoma and a third with an adrenal myelolipoma.

I regret to say, that the article should not be approved for indexing. The article has scientific misinformation. For instance, the authors indicate that the usual examination for the pheochromocytoma is the ultrasound or that only $10 \%$ of patients with pheochromocytoma do not present hypertension, whereas the truth is that many patients with pheochromocytoma have normal blood pressure levels (see reference list and attached document for examples) and the diagnostic imaging of choice after the biochemical confirmation of a pheochromocytoma is the CT (or MRI in certain cases). Another example is the part where the authors indicate that adrenalectomy is totally contradicted in cases of synchronous metastatic disease. That is also misleading. In many cases disease debulking has been associated with better survival for some patients.

The authors do not describe in detail the physical examination, or the diagnostic procedures followed in daily routine care for adrenal lesions (e.g., concentrations of plasma or urinary metanephrines, steroids, dexamethasone suppression test, assays used for the metabolites, upper cut offs of reference intervals). The discussion does not include information or conclusions based on findings that could add to our understanding of the disease processes, diagnosis or treatment.

The article will require copy editing. In addition, the article adds little on what is already known in the literature and lacks novelty.

\section{References}


1. Neumann HP, Berger DP, Sigmund G, Blum U, et al.: Pheochromocytomas, multiple endocrine neoplasia type 2, and von Hippel-Lindau disease.N Engl J Med. 1993; 329 (21): 1531-8 PubMed Abstract | Publisher Full Text

2. Eisenhofer G, Walther MM, Huynh TT, Li ST, et al.: Pheochromocytomas in von Hippel-Lindau syndrome and multiple endocrine neoplasia type 2 display distinct biochemical and clinical phenotypes.J Clin Endocrinol Metab. 2001; 86 (5): 1999-2008 PubMed Abstract | Publisher Full Text 3. Mannelli M, Ianni L, Cilotti A, Conti A: Pheochromocytoma in Italy: a multicentric retrospective study.Eur J Endocrinol. 1999; 141 (6): 619-24 PubMed Abstract | Publisher Full Text

4. Baguet JP, Hammer L, Mazzuco TL, Chabre O, et al.: Circumstances of discovery of phaeochromocytoma: a retrospective study of 41 consecutive patients.Eur J Endocrinol. 2004; 150 (5): 681-6 PubMed Abstract | Publisher Full Text

5. Ito Y, Obara T, Yamashita T, Kanbe M, et al.: Pheochromocytomas: tendency to degenerate and cause paroxysmal hypertension.World J Surg. 1996; 20 (7): 923-6; discussion 927 PubMed Abstract | Publisher Full Text

6. Bravo E, Fouad-Tarazi F, Rossi G, Imamura M, et al.: A reevaluation of the hemodynamics of pheochromocytoma.Hypertension. 1990; 15 (2 Suppl): I128-31 PubMed Abstract | Publisher Full Text

7. Streeten D: Mechanisms of orthostatic hypotension and tachycardia in patients with pheochromocytoma. American Journal of Hypertension. 1996; 9 (8): 760-769 Publisher Full Text 8. Levenson JA, Safar ME, London GM, Simon AC: Haemodynamics in patients with phaeochromocytoma.Clin Sci (Lond). 1980; 58 (5): 349-56 PubMed Abstract | Publisher Full Text 9. Lance JW, Hinterberger H: Symptoms of pheochromocytoma, with particular reference to headache, correlated with catecholamine production.Arch Neurol. 1976; 33 (4): 281-8 PubMed Abstract | Publisher Full Text

Is the background of the cases' history and progression described in sufficient detail? No

Are enough details provided of any physical examination and diagnostic tests, treatment given and outcomes?

No

Is sufficient discussion included of the importance of the findings and their relevance to future understanding of disease processes, diagnosis or treatment?

No

Is the conclusion balanced and justified on the basis of the findings?

No

Competing Interests: No competing interests were disclosed.

Reviewer Expertise: Adrenal diseases

I confirm that I have read this submission and believe that I have an appropriate level of expertise to state that I do not consider it to be of an acceptable scientific standard, for reasons outlined above. 


\section{Author Response 09 May 2022}

Fauriski F Prapiska, Faculty of Medicine Universitas Sumatera Utara - H. Adam Malik General Hospital, Medan, Indonesia

Thank you for your thoughtful remarks. We appreciate the time and effort that you have dedicated to provide feedback on our manuscript and are grateful for the comments on our paper. We would like to address a few topics that have been raised.

1. We thank the reviewer for pointing this out. USG is utilized as an initial diagnostic technique, not as a gold standard. According to Campbell-Walsh-Wein Urology, Computerized Tomography Scan is the gold standard in adrenal imaging.

2. We appreciate the reviewers insightful suggestion. However, as stated by Zuber, Kantorovich, and Pack in the metabolism Clinics of North America Journal, roughly $5 \%$ to $15 \%$ of pheochromocytoma patients have normal blood pressure.

Once again, we thank you for the time you put in reviewing our paper.

Best regards,

Fauriski F Prapiska (Corresponding author)

Competing Interests: No commenting interest were disclosed

The benefits of publishing with F1000Research:

- Your article is published within days, with no editorial bias

- You can publish traditional articles, null/negative results, case reports, data notes and more

- The peer review process is transparent and collaborative

- Your article is indexed in PubMed after passing peer review

- Dedicated customer support at every stage

For pre-submission enquiries, contact research@f1000.com 